\title{
Sox3 Expression Identifies Neural Progenitors in Persistent Neonatal and Adult Mouse Forebrain Germinative Zones
}

\author{
TSU-WEI WANG, ${ }^{1}$ GREGORY P. STROMBERG,${ }^{1}$ JUSTIN T. WHITNEY, ${ }^{1}$ \\ NATHAN W. BROWER, ${ }^{1}$ MICHAEL W. KLYMKOWSKY, ${ }^{2}$ AND JACK M. PARENT ${ }^{1 *}$ \\ ${ }^{1}$ Department of Neurology and Neuroscience Graduate Program, University of Michigan \\ Medical Center, Ann Arbor, Michigan \\ ${ }^{2}$ Department of Molecular, Cellular and Developmental Biology, University of Colorado, \\ Boulder, Colorado
}

\begin{abstract}
Neural precursors persist throughout life in the rodent forebrain subventricular zone (SVZ) and hippocampal dentate gyrus. The regulation of persistent neural stem cells is poorly understood, in part because of the lack of neural progenitor markers. The Sox B1 subfamily of HMG-box transcription factors (Sox1-3) is expressed by precursors in the embryonic nervous system, where these factors maintain neural progenitors in an undifferentiated state while suppressing neuronal differentiation. Sox2 expression persists in germinative zones of the adult rodent brain, but Sox3 expression in the postnatal brain remains largely unexplored. Here we examine Sox3 expression in the neonatal and adult mouse brain to gain insight into its potential involvement in regulating persistent neural stem cells and neurogenesis. We also investigate Sox3 expression during expansion and neural differentiation of postnatal mouse SVZ neural stem cell and human embryonic stem cell (hESC) cultures. We find that Sox3 is expressed transiently by proliferating and differentiating neural progenitors in the SVZ-olfactory bulb pathway and dentate gyrus. Sox3 immunoreactivity also persists in specific postmitotic neuronal populations. In vitro, high Sox3 protein expression levels in undifferentiated, SVZ-derived neurospheres decline markedly with differentiation. Sox3 immunoreactivity in hESCs appears upon differentiation to neural progenitors and then decreases as cells differentiate further into neurons. These findings suggest that Sox3 labels specific stages of hESC-derived and murine neonatal and adult neural progenitors and are consistent with a role for Sox3 in neural stem cell maintenance. Persistent Sox3 expression in some mature neuronal populations suggests additional undefined roles for Sox3 in neuronal function. J. Comp. Neurol. 497:88-100, 2006. ๑ 2006 Wiley-Liss, Inc.
\end{abstract}

Indexing terms: Sox3; subventricular zone; dentate gyrus; neural stem cell; neurogenesis

Forebrain neurogenesis persists into adulthood in the mammalian subventricular zone (SVZ) adjacent to the lateral ventricle and the subgranular zone (SGZ) of the hippocampal dentate gyrus (Altman and Das, 1965; Altman, 1969a,b; Cameron et al., 1993; Luskin, 1993; Lois and Alvarez-Buylla, 1994; Kuhn et al., 1996; Eriksson et al., 1998). Neural progenitors in the SVZ generate neuroblasts, which migrate tangentially along the rostral migratory stream (RMS) to the olfactory bulb and differentiate into interneurons (Luskin, 1993, 1998; Lois and Alvarez-Buylla, 1994), whereas neuroblasts generated in the SGZ migrate radially a short distance into the dentate granule cell layer and differentiate into granule cells
(Cameron et al., 1993; Kuhn et al., 1996). Neuroblasts in the neonatal and adult mammalian dentate gyrus and

Grant sponsor: National Institutes of Health; Grant number: NS42143; Grant number: HD044775; Grant sponsor: American Federation for Aging Research.

*Correspondence to: Jack M. Parent, Department of Neurology, 4412 Kresge III, 200 Zina Pitcher Place, Ann Arbor, MI 48109-0585. E-mail: parent@umich.edu

Received 29 November 2005; Revised 26 January 2006; Accepted 30 January 2006

DOI 10.1002/cne.20984

Published online in Wiley InterScience (www.interscience.wiley.com). 
SVZ-olfactory bulb pathway express immature neuronal markers such as doublecortin (DCx), polysialylated neural cell adhesion molecule (PSA-NCAM), and neuron-specific $\beta$-tubulin (Peretto et al., 1997; Gleeson et al., 1999). Recent evidence indicates that adult-generated olfactory bulb and dentate gyrus neurons are functionally incorporated into existing neural circuits (Carlen et al., 2002; van Praag et al., 2002; Belluzzi et al., 2003). Studies suggest that adult neurogenesis is important for hippocampusdependent learning and olfactory discrimination (Corotto et al., 1994; Kempermann et al., 1997; Gould et al., 1999; Gheusi et al., 2000; Shors et al., 2001; Rochefort et al., 2002).

Neonatal and adult neural progenitors also can be isolated from the SVZ and SGZ and cultured to form neurospheres. The progenitors self-renew in vitro in the presence of mitogens such as epidermal growth factor (EGF) and basic fibroblast growth factor (bFGF; Reynolds and Weiss, 1992; Gritti et al., 1996; Seaberg and van der Kooy, 2002). Mitogen withdrawal induces neurophere-derived cells to differentiate into neurons, astrocytes, and oligodendrocytes (Reynolds and Weiss, 1992). Several classes of molecules, including growth factors and neuromodulators, as well as other cell types, such as astrocytes, modulate adult neurogenesis in vivo or in vitro (Craig et al., 1996; Kuhn et al., 1997; Zigova et al., 1998; Wagner et al., 1999; Song et al., 2002). Adult neural stem cells in rodent SVZ and dentate gyrus have been identified in vivo as glial fibrillary acidic protein (GFAP)-expressing radial glia-like cells (Doetsch et al., 1999; Seri et al., 2001). Unlike the case for hematopoietic stem cells, however, markers to identify neural stem cells specifically in situ remain unidentified.

SRY-related high mobility group (HMG)-box proteins are key regulators for cell fate decisions. They act either as classical transcription factors or as architectural components of chromatin (Pevny and Lovell-Badge, 1997). Among them, the intronless Sox B1 subfamily (Sox1-3), which shares a conserved region in the C-terminal in addition to the HMG box, is expressed by the neuroepithelium in the embryonic nervous system (Collignon et al., 1996). Prior to its expression in the developing nervous system, Sox2 is expressed as early as in the inner cell mass stage, and Sox2 and Sox3 also are expressed in the primitive ectoderm and epiblast (Collignon et al., 1996; Wood and Episkopou, 1999). In adult mouse brains, Sox2 expression is detected in the SVZ and RMS (Zappone et al., 2000). Experiments with chick in ovo eletroporation show that the neurogenic specification of proneural proteins depends on the inhibition of Sox1-3 expression (Bylund et al., 2003; Graham et al., 2003). Sox2-deficient mice also show reduced adult neurogenesis in the SVZ and SGZ (Ferri et al., 2004). These findings suggest that Sox1-3 may maintain neural progenitor cells in an undifferentiated state and suppress neuronal differentiation (Pevny and Rao, 2003).

Sox3 is an X-linked gene (Stevanovic et al., 1993), and mutations in humans cause a syndrome of mental retardation with growth hormone deficiency (Laumonnier et al., 2002). Knockout studies in mice show that Sox3 is involved in the formation of the hypothalamic-pituitary axis (Rizzoti et al., 2004). Consistently with a role in neural development, Sox3 is up-regulated transiently during retinoic acid-induced neural differentiation of NT2 embryonic carcinoma cells (Stevanovic, 2003). Expression of Sox3 mRNA has been detected in the perinatal forebrain SVZ (Karsten et al., 2003); however, the expression pattern, cellular identities, and function of Sox3 in the neonatal or adult mammalian brain are unexplored. Here we use an anti-Sox3 antibody to detect the spatiotemporal expression patterns of Sox3 protein in the neonatal and adult mouse brain and in neural stem cell cultures derived from postnatal mouse SVZ or human embryonic stem cells (hESCs).

\section{MATERIALS AND METHODS Neurosphere cultures}

Postnatal day 15 (P15) CD-1 albino mice (Charles River) were anesthetized with $\mathrm{CO}_{2}$ and their brains removed. Brains were cut into 2 -mm-thick coronal blocks, and the lateral SVZ tissue was dissected, minced into small pieces, and dissociated with trypsin. Approximately $3-8 \times 10^{4}$ SVZ cells (pooled from three or four brains) per $60-\mathrm{mm}$ dish were cultured in Dulbecco's modified Eagle's medium (DMEM)/F12 nutrient (1:1; Gibco, Grand Island, NY) containing $20 \mathrm{ng} / \mathrm{ml}$ epidermal growth factor (EGF; Sigma, St. Louis, MO) and $10 \mathrm{ng} / \mathrm{ml}$ basic fibroblast growth factor (bFGF; Sigma). Primary NS were cultured for 6-7 days in vitro (DIV), mechanically dissociated and plated for differentiation at $1 \times 10^{5}$ cells/well in 24-well plates (Corning-Costar, Cambridge, MA) coated with polyornithine (Sigma).

\section{hESC cultures}

Differentiation experiments were conducted with the H1 hESC line (Thomson et al., 1998) obtained from WiCell Inc. (Madison, WI). Undifferentiated cells were maintained as described previously (Thomson et al., 1998). hESCs were grown on feeder cell layers of irradiated mouse embryonic fibroblasts (MEFs), which were isolated and plated by using standard tissue culture techniques. Neuronal differentiation was initiated under maintenance culture conditions. hESC colonies were grown to high density, leading to the development of embryoid bodies (EBs). EBs were then passaged onto gelatin-coated plates without feeder cells. The cells were cultured for 10 days in a medium formulation containing DMEM/F12, 20\% fetal bovine serum, L-glutamine, and nonessential amino acids (to promote differentiation) and then fixed with 4\% PFA.

\section{In vivo bromodeoxyuridine (BrdU) labeling and tissue processing}

Subjects were CD-1 albino mice (Charles River Laboratories) ranging in age from postnatal day 2 to adulthood. Animals were group housed on a 12-hour light-dark cycle and provided with food and water ab libitum. All procedures were performed in accordance with the University Committee on Use and Care of Animals (UCUCA) at the University of Michigan. Pulse BrdU labeling was used to identify mitotically active cells. BrdU (100 mg/kg; Roche, Indianapolis, IN) dissolved in phosphate-buffered saline (PBS; pH, 7.4) was administered once by i.p. injection to postnatal day (P) 2, 7, 14 or adult CD-1 mice $(n=4$ per group), and 2 hours later animals were killed by anesthetic overdose and the brains perfusion-fixed with $0.9 \%$ $\mathrm{NaCl}$, followed by $4 \%$ PFA. Brains were removed and postfixed overnight in $4 \%$ PFA, cryoprotected with $20 \%$ sucrose, frozen in powdered dry ice, and sectioned coro- 
TABLE 1. Details of Primary Antibodies Used

\begin{tabular}{|c|c|c|c|c|c|}
\hline Antibody & Species & Company (reference) & Titer & Catalog No. & Immunogen \\
\hline Class III $\beta$-tubulin & Mouse & Covance (Lee et al., 1990) & $1: 400$ & MMS-435P & Rat brain microtubules ${ }^{1}$ \\
\hline BrdU & Rat & Serotec (Kempermann et al., 1997) & $1: 100$ & MCA2060 & BrdU in single-stranded $\mathrm{DNA}^{2}$ \\
\hline Calretinin & Mouse & Chemicon (Nunzi et al., 2001) & $1: 4,000$ & MAB1568 & Recombinant rat calretinin ${ }^{3}$ \\
\hline GFAP & Mouse & Sigma (Latov et al., 1979) & $1: 500$ & G3893 & Purified GFAP from pig spinal cord ${ }^{4}$ \\
\hline NeuN & Mouse & Chemicon (Mullen et al., 1990) & $1: 1,000$ & MAB377 & Mouse brain nuclei ${ }^{5}$ \\
\hline Nestin & Mouse & $\begin{array}{l}\text { Dev. Studies Hybridoma Bank (Hockfield } \\
\text { and McKay, 1985) }\end{array}$ & $1: 10$ & Rat401 & Homogenized rat spinal cord $^{6}$ \\
\hline PSA-NCAM & Mouse & $\begin{array}{l}\text { Dev. Studies Hybridoma Bank (Dodd et } \\
\text { al., 1988; Shen et al., 1997) }\end{array}$ & $1: 200$ & $5 \mathrm{~A} 5$ & Rat embryonic spinal cord membranes ${ }^{7}$ \\
\hline Sox2 & Rabbit & Chemicon (Komitova and Eriksson, 2004) & $1: 5,000$ & AB5603 & Synthetic peptide from human Sox $2^{8}$ \\
\hline Sox3 & Rabbit & (Zhang et al., 2003) & $1: 4,000$ & & See text \\
\hline
\end{tabular}

${ }^{1}$ Western blot reveals a band of about $50 \mathrm{kD}$ with this antibody; it is highly expressed in immature neurons (Doetsch et al., 1997).

${ }^{2}$ The antibody also recognizes BrdU attached to a protein carrier and free BrdU. It does not cross-react with thymidine but does react weakly with chlorodeoxyuridine.

${ }^{3}$ The antibody recognizes a $30-\mathrm{kD}$ band on immunoblot. It is expressed by immature dentate granule cells (Brandt et al., 2003) and other neuronal subtypes.

${ }^{4}$ A 52-kD band is found on Western blot with this antibody. GFAP is expressed by radial glia-like stem cells in SVZ and dentate gyrus (Doetsch et al., 1999; Seri et al., 2001) and astrocytic tube-forming cells in the RMS (Peretto et al. 1997).

${ }^{5}$ Recognizes two to three bands in the $46-48-\mathrm{kD}$ range and possibly another band of approximately $66 \mathrm{kD}$ by Western blot. The antigen is expressed by mature neurons in adult mouse dentate gyrus (Brandt et al., 2003).

${ }^{6}$ Recognizes a $200-\mathrm{kD}$ band on Western blot. Nestin is expressed by radial glia-like neural progenitors in adult mouse SVZ and dentate gyrus (Seri et al., 2001). ${ }^{7}$ Antibody yields bands ranging from about 180 to $200 \mathrm{kD}$ (due to variable numbers of PSA residues). PSA-NCAM is expressed by immature neurons in postnatal germinative zones

${ }^{8}$ The peptide sequence is SSSPPVVTSSSHSRAPC. The antibody recognizes a 34-kD band in nuclear extracts not observed in cytosolic extracts on Western blots. Sox2 is expressed in neural progenitor cells (Komitova and Eriksson, 2004).

nally at $40 \mu \mathrm{m}$ thickness. To identify differentiating and postmitotic, adult-generated cells, some adult mice were killed $4(\mathrm{n}=4)$ or $14(\mathrm{n}=4)$ days after a single $100 \mathrm{mg} / \mathrm{kg}$ i.p. BrdU injection and the brains processed as described above.

\section{Immunocytochemistry}

Cell cultures were fixed with 4\% PFA for 30 minutes and rinsed three times with PBS. For immunofluorescence labeling, sections or cells were rinsed in Tris-buffered saline (TBS; pH 7.4) and incubated in blocking buffer for 1 hour prior to incubation with the following primary antibodies (see Table 1) alone or in species-appropriate combinations for 48 hours at $4^{\circ} \mathrm{C}$ : rabbit anti-Sox3 (Zhang et al., 2003), rabbit anti-Sox2, mouse IgM anti-PSA-NCAM (5A5 clone), mouse anti-GFAP, mouse anti-calretinin, mouse anti-NeuN, or mouse anti-class III $\beta$-tubulin (TuJ1 clone). After three TBS washes, sections or cells were incubated with Alexa Fluor 594- or 488-conjugated goat anti-rabbit and anti-mouse IgG secondary antibody (1: 200; Molecular Probes, Eugene, OR) or with fluorescein isothiocyanate (FITC)-conjugated anti-mouse IgM secondary antibodies (1:200; Jackson Immunoresearch, West Grove, PA) at room temperature for 2 hours, washed three times with TBS, mounted on slides, and coverslipped with antifade medium (Pro-Long; Molecular Probes). For BrdU immunohistochemistry, sections were incubated with $2 \mathrm{~N}$ $\mathrm{HCl}$ at $37^{\circ} \mathrm{C}$ for 30 minutes to denature DNA, then neutralized with $0.1 \mathrm{M}$ sodium borate $(\mathrm{pH} 8.5)$ for 10 minutes. After TBS washes, sections were incubated with rat antiBrdU (1:50; Serotec) and rabbit anti-Sox3 antibodies at $4^{\circ} \mathrm{C}$ for 48 hours and then processed as described above with Alexa 594-conjugated goat anti-rat IgG and Alexa 488 goat anti-rabbit secondary antibodies (1:200). In double-labeling experiments, some sections were processed with one of the primary antibodies omitted as a control, and nonspecific double labeling was not observed. For BrdU labeling, the denaturing steps were not performed on some sections as a control, and no nuclear staining was seen. For all other antibodies, which were used as markers, accurate subcellular and tissue expression patterns were confirmed based on prior reports (cited in the footnotes to Table 1).
For Sox3 diaminobenzidine (DAB) staining, sections were processed as follows: rinses with Tris buffer and then Tris buffer with Triton X-100/bovine serum albumin (BSA), blocking with $10 \%$ normal goat serum in Tris buffer with Triton X-100/BSA for 1 hour prior, and then incubation with anti-Sox 3 antibody at $4^{\circ} \mathrm{C}$ overnight. After Tris buffer washes, sections were incubated with biotinylated goat anti-rabbit IgG (1:200; Jackson Immunoresearch) and then avidin-biotin peroxidase (ABC) complex (Vector, Burlingame, CA). For color reaction, sections were then incubated with stable DAB (Invitrogen, Calsbad, CA). Images were captured with a Leica DSM-IRB epifluorescence microscope and Spot-RT digital camera or, for double-labeling, as z-series thin optical sections with a Zeiss LSM-510 confocal microscope. Digital images were imported into Adobe Photoshop v.6.0 (Adobe Systems, Mountain View, CA) for color merging. Contrast and brightness were adjusted slightly to keep background intensity levels comparable among the animals of different ages.

\section{Western blots}

The olfactory bulbs and hippocampi of adult CD-1 mice and whole brains of adult zebrafish were dissected out and homogenized, and protein was extracted. Frozen adult human hippocampal tissue was obtained from the University of Miami Brain and Tissue Bank with University of Michigan Institutional Review Board approval. Protein extracts were prepared in sample buffer $(50 \mathrm{mM}$ Tris-HCl, $1 \%$ NP-40, 0.25\% Na-deoxycholate, $150 \mathrm{mM} \mathrm{NaCl}, 1 \mathrm{mM}$ EDTA, $1 \mathrm{mM}$ phenylmethylsulfonyl fluoride, $1 \mu \mathrm{g} / \mathrm{ml}$ aprotinin, leupeptin, and pepstatin). The extracts were subjected to SDS-PAGE and then Western blot analysis to detect Sox3 and Sox2 proteins.

\section{RESULTS Specificity of Sox3 antibody}

We first sought to determine whether an anti-Sox3 antibody developed using the C-terminal 20 amino acids of Xenopus Sox3 (Zhang et al., 2003) and cross-reactive with zebrafish Sox3 (Zhang et al., 2004) would recognize mouse 


\section{Zf Mh Mob $\mathrm{Hh}$}

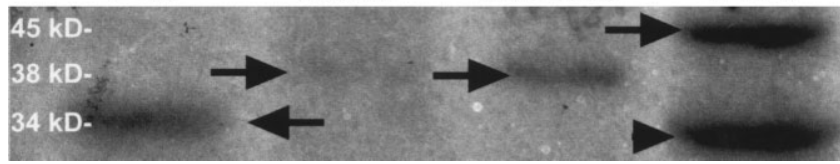

Fig. 1. Western blot of Sox3 protein expression in zebrafish brain, mouse hippocampal formation and olfactory bulb, and human hippocampus. The anti-Sox3 antibody raised to a peptide of Xenopus Sox3 recognizes a $34-\mathrm{kD}$ band in whole zebrafish brain, a $38-\mathrm{kD}$ band in mouse olfactory bulb and hippocampus, and a $45-\mathrm{kD}$ band in human hippocampus (arrows). The antibody probably also binds to human Sox2 protein, because it yields an additional 34-kD band (arrowhead) with human hippocampal protein extract. Zf, zebrafish; Mh, mouse hippocampus; Mob, mouse olfactory bulb; Hh, human hippocampus.

and human Sox3. Western blotting therefore was used to test the specificity of the antibody. The anti-Sox3 antibody was applied to protein extracted from mouse olfactory bulb, human hippocampus, and zebrafish whole brain. It recognized protein bands of 38,45 , and $34 \mathrm{kD}$, respectively, which are the appropriate sizes of Sox3 protein for each species (Fig. 1). To determine whether the anti-Sox3 antibody cross-reacted with Sox 2 protein, we examined whether the Sox3 antibody recognized a $34-\mathrm{kD}$ band, the expected size of mouse or human Sox2 protein (Stevanovic et al., 1993, 1994; Collignon et al., 1996; Malas et al., 1997). When applied to the mouse olfactory bulb sample, the anti-Sox3 antibody did not yield a $34-\mathrm{kD}$ band, although a rabbit anti-mouse Sox2 antibody did (data not shown). However, a band of this size was found with the anti-Sox3 antibody in the human hippocampal tissue sample. These data suggest that the anti-Sox3 antibody recognizes Sox3, and not Sox2, in mouse. Although the antibody may also recognize Sox 2 in human tissue by Western blot, the data on hESC Sox2 and Sox3 expression described below argue against the possibility that the antibody recognizes human Sox2 by immunocytochemistry.

\section{Ontogeny of Sox3 expression in postnatal mouse brain}

To map the spatiotemporal expression pattern of Sox3 protein in postnatal mouse brain, we performed immunohistochemistry on P2, P7, P14, and adult brain sections with the anti-Sox3 antibody. Sox3 expression was detected in both persistent neurogenic brain regions, the SVZ and dentate gyrus, from P2 to adulthood (Fig. 2A,B,E,F,I,J). Sox3 immunoreactivity also appeared in the RMS (Fig. $2 \mathrm{D}, \mathrm{H})$ and the olfactory bulb subependymal, granular, and
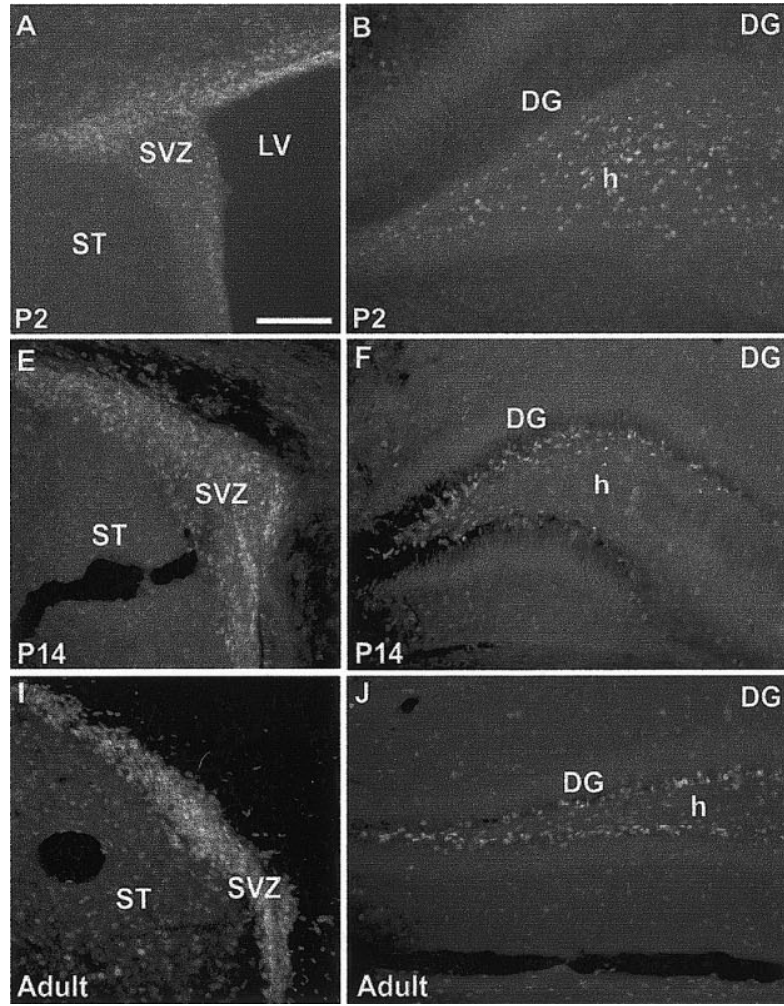

Fig. 2. Anti-Sox3 immunostaining of postnatal day (P) 2 (A,B), P7 (C,D), P14 (E,F), or adult (G-L) mouse brains. A, B, E, F, I, and J are coronal immunofluorescence-stained sections; C, D, G, H, K, and L are sagittal immunoperoxidase-stained sections. Sox3 is expressed in the SVZ-olfactory bulb pathway from P2 to adulthood (A,C-E,G-I). In the dentate gyrus, Sox3 is expressed in the hilus and subgranular zone (SGZ) at P2 (B) but is more restricted to the SGZ in P14 (F) and adult $(\mathrm{J})$ mice. Sox3 protein also is expressed in nonneurogenic regions of
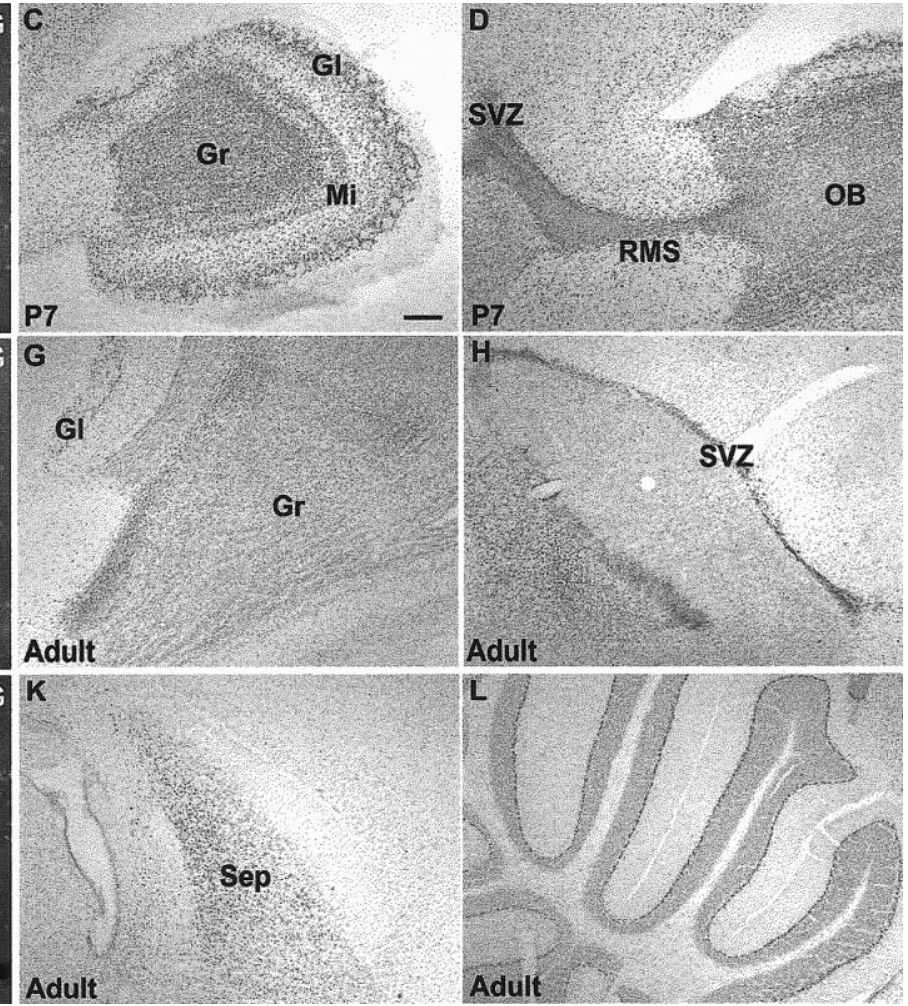

the adult, such as the septum $(\mathrm{H}, \mathrm{K})$ and Purkinje cell layer of the cerebellum (L). Light methyl green counterstain in H, K, and L. ST, striatum; SVZ, subventricular zone; LV, lateral ventricle; DG, dentate gyrus; h, hilus; Gl, glomerular layer; Gr, granular layer; Mi, mitral cell layer; RMS, rostral migratory stream; OB, olfactory bulb; Sep, septum. Scale bars $=50 \mu \mathrm{m}$ in A (applies to A,B,E,F,I,J); $200 \mu \mathrm{m}$ in C (applies to C,D, G,H,K,L). 
TABLE 2. Summary of Sox3 Expression in Adult Mouse Brain

\begin{tabular}{|c|c|}
\hline Region & Expression level $^{1}$ \\
\hline \multicolumn{2}{|l|}{ Olfactory bulb } \\
\hline Subependymal zone & +++ \\
\hline Granular layer & +++ \\
\hline Internal plexiform layer & + \\
\hline Mitral cell layer & ++ \\
\hline External plexiform layer & + \\
\hline Glomerular layer & +++ \\
\hline Olfactory tubercle & +++ \\
\hline Cortex & $+1-$ \\
\hline Corpus callosum & - \\
\hline Subventricular zone & +++ \\
\hline Bed nucleus stria terminalis & ++ \\
\hline \multicolumn{2}{|l|}{ Septum } \\
\hline Lateral, dorsal part & ++ \\
\hline Lateral, intermediate part & + \\
\hline Lateral, ventral part & + \\
\hline Striatum & $+1-$ \\
\hline \multicolumn{2}{|l|}{ Hippocampal formation } \\
\hline CA1-3 & + \\
\hline Dentate granule cell layer & $+1-$ \\
\hline Subgranular zone & +++ \\
\hline Hilus & + \\
\hline \multicolumn{2}{|l|}{ Habenular nucleus } \\
\hline Medial & - \\
\hline Lateral & ++ \\
\hline Thalamus & - \\
\hline Superior colliculus & $+1-$ \\
\hline Inferior colliculus & $+1-$ \\
\hline \multicolumn{2}{|l|}{ Hypothalamus } \\
\hline Dorsomedial & $+1-$ \\
\hline Ventromedial & ++ \\
\hline Midbrain & $+1-$ \\
\hline Cerebellum (Purkinje cell layer) & +++ \\
\hline Pons & $+1-$ \\
\hline Medulla & - \\
\hline
\end{tabular}

glomerular layers at all ages examined (Fig. 2C,G). Sox3 was expressed not only in the SGZ but also in the hilus on P2 (Fig. 2B). With increasing age from P7 to adulthood, dentate gyrus Sox3 expression became more restricted to the SGZ (Fig. 2F,J). In addition to neurogenic regions of the mature brain, Sox3 immunoreactivity was detected in the adult mouse olfactory tubercle, dorsolateral septum, cerebellar Purkinje cell layer, lateral habenular nucleus, and ventromedial part of the hypothalamus (Fig. 2H,K,L, Table 2). More scattered Sox 3 expression appeared in the cortex and striatum of adults (Fig. 2I, and data not shown). No Sox3 immunoreactivity appeared in the corpus callosum or other fiber tracts.

\section{Subsets of Sox3-expressing cells actively proliferate in postnatal mouse brain}

To examine whether Sox3-positive cells in postnatal neurogenic brain regions proliferate, neonatal (P2, 7, and 14) and adult mice received a single pulse BrdU injection, and 2 hours later the patterns of BrdU and Sox3 immunoreactivities were examined. The SVZ and RMS were analyzed first. Despite the presence of many dividing cells and intense Sox3 expression in the SVZ from P2 to P14, minimal overlap existed between these populations; few double-labeled cells were found in the dorsolateral and ventral SVZ (Fig. 3A,B,D-E'). Sox3-positive cells were located closer to the ventricle than BrdU-labeled cells in both the SVZ and the RMS of neonates (Fig. 3A,B,D$\left.\mathrm{E}^{\prime}, \mathrm{G}\right)$. In adults, most of the BrdU-positive cells in the SVZ $(90 \%)$ and nearly all in the RMS coexpressed Sox3 (Fig. $\left.3 \mathrm{C}, \mathrm{F}, \mathrm{F}^{\prime}, \mathrm{H}-\mathrm{H}^{\prime \prime}\right)$. We next examined proliferating cells in the dentate gyrus. In the P2 dentate, BrdU-labeled cells appeared mainly in the SGZ, whereas Sox3- immunoreactive cells were scattered in the hilus (Fig. 3I). The overlap of these two populations progressively increased with age. At P7, fewer than 3\% of SGZ BrdUpositive cells were Sox3-positive. By P14, 31\% of BrdUpositive cells in the SGZ coexpressed Sox3 (Fig. 3J), and Sox3-labeled cells were closer to the SGZ than at younger ages. In adults, most of the dentate Sox3-positive cells were found in the SGZ; all of the SGZ BrdU-labeled cells expressed Sox3 (Fig. 3K). Many of the adult SGZ Sox3immunostained cells that were BrdU negative likely were proliferative cells that were not in S phase 2 hours earlier when BrdU was injected. These data suggest that Sox3 is expressed by relatively quiescent, neural stem/progenitor cells in the neonatal forebrain, and that with age the progenitors proliferate more actively and assume a slightly more differentiated state.

The pattern of Sox3 expression during neuronal differentiation in the adult was next studied. Adult mice received BrdU and were killed 2 hours, 4 days, or 14 days later. Two hours after a single pulse BrdU injection, nearly all of the BrdU-positive cells in the RMS, SVZ, and SGZ expressed Sox3 (Figs. 3C, F',H,K, 4A,D$\left.\mathrm{D}^{\prime \prime}\right)$. By 4 days after BrdU administration, only about $7 \%$ of the BrdU-positive cells in the SGZ still expressed Sox3 (Fig. 4B); the percentage decreased further to $4 \%$ at 14 days (Fig. 4C,E-E' ${ }^{\prime \prime}$ ). We next examined the SVZolfactory bulb pathway. At 2 hours after BrdU labeling, many labeled cells were present in the SVZ, and few BrdU-immunoreactive cells appeared in the olfactory bulb. As described above, nearly all BrdU-positive cells expressed Sox3. The BrdU labeling pattern was reversed by 4 days, with many BrdU-positive cells found in the olfactory bulb subependymal zone, and some remaining in the SVZ. Most of the BrdU-labeled cells in both regions continued to be Sox3-positive (data not shown). By 14 days after BrdU injections, many BrdUlabeled cells had migrated to the granular cell layer of the olfactory bulb, one of the final destinations of SVZ neuroblasts, and appeared to be Sox3 negative (data not shown). BrdU-positive cells remaining in the SVZ were located mainly in the ventral portion, and nearly all coexpressed Sox3 (data not shown). These results suggest that adult-generated neural progenitors in both neurogenic regions down-regulate Sox3 expression after they exit the cell cycle and begin to differentiate.

\section{Phenotypes of Sox3-immunoreactive cells in the adult SVZ-olfactory bulb pathway}

To determine the cellular identity of Sox3-positive cells in the adult mouse olfactory bulb, RMS, and SVZ, we performed immunofluorescent double labeling for Sox3 and cell-type-specific markers. Immunostaining was analyzed by confocal microscopy using z-series with thin optical sections. In the SVZ, about $56 \%$ of Sox3-positive cells in the SVZ expressed the immature neuronal marker $\beta$-tubulin (Fig. 5A), and a similar proportion coexpressed another neuroblast marker, PSA-NCAM (Fig. 5B). Approximately $28 \%$ of Sox3-immunoreactive cells coexpressed the neural stem cell and astroglial marker glial fibrillary acidic protein (GFAP); most of the double-labeled cells were surrounded by $\mathrm{GFAP}^{+} / \mathrm{Sox} 3^{-}$cells (Fig. $5 \mathrm{C}$ ). Some Sox3-immunoreactive cells in the SVZ also immunolabeled for the neural progenitor cell marker nestin (data not shown). In the RMS, most Sox3-positive cells coexpressed $\beta$-tubulin and were surrounded by GFAP- 

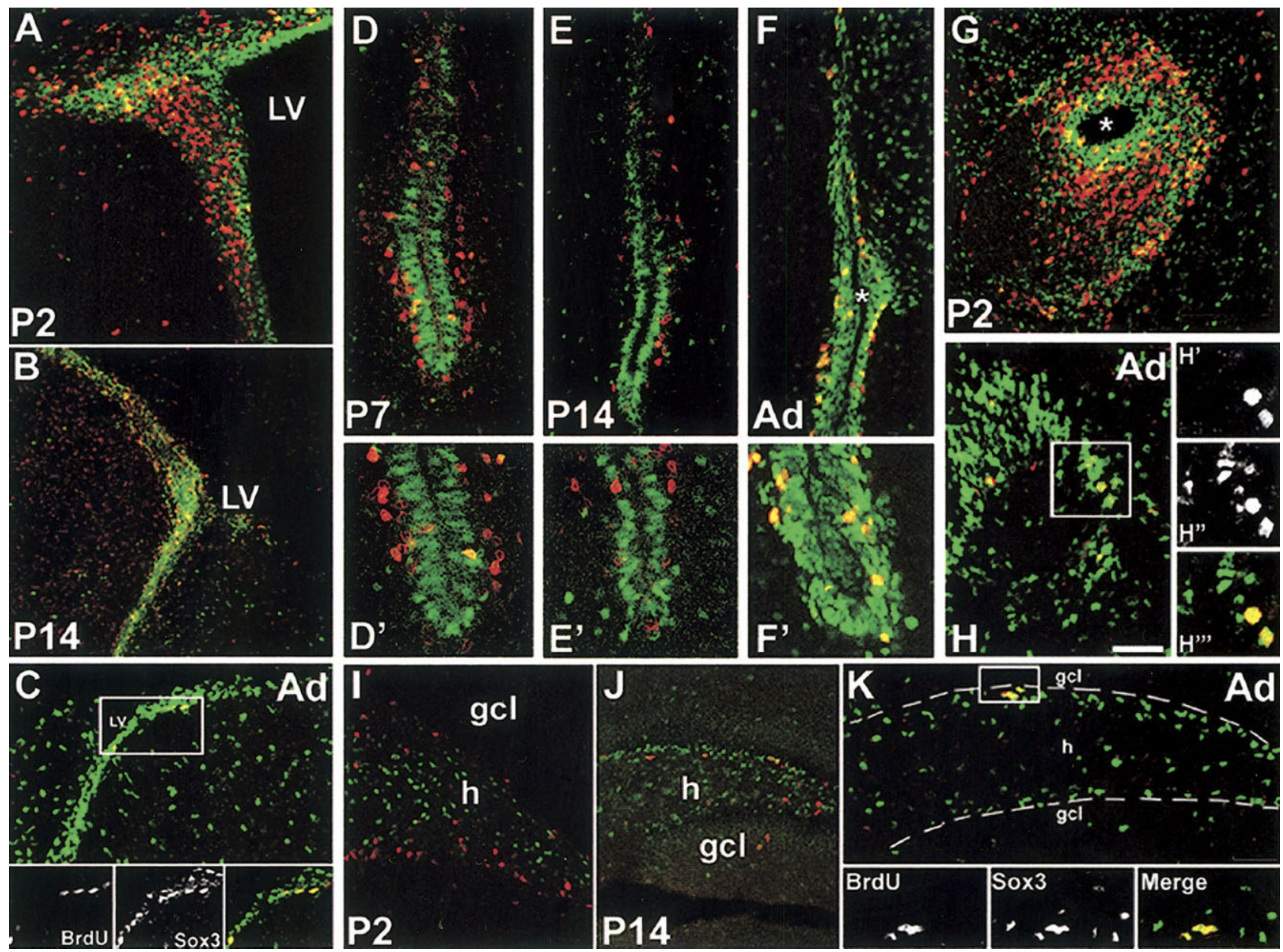

Fig. 3. Coronal confocal images of mouse brain sections doubly immunostained for Sox3 (green in all panels) and BrdU (red in all panels) in the SVZ, RMS, and dentate SGZ. BrdU was injected 2 hours before perfusion. A-F: In the SVZ, Sox3-positive cells appear closer to the lateral ventricle (LV) than BrdU-labeled cells at P2 (A), P7 (D, D'), and P14 (B,E, $\left.\mathrm{E}^{\prime}\right)$ with little overlap compared with the adult, in which most BrdU-positive cells in the SVZ coexpress Sox3 (C,F, F'). G,H: In the RMS, Sox3-immunoreactive cells are closer to the ventricular lumen (asterisk in G) than BrdU-positive cells at P2, whereas nearly all BrdU-positive cells $\left(\mathrm{H}^{\prime}\right)$ also express Sox3 $\left(\mathrm{H}^{\prime \prime}\right)$ in adult $\left(\mathrm{H}-\mathrm{H}^{\prime \prime \prime}\right)$.

I-K: Double immunolabeling in the dentate gyrus shows largely nonoverlapping populations of BrdU- and Sox3-immunoreactive cells in the hilus (h) at P2 (I) and P14 (J), whereas in the adult all BrdUlabeled cells coexpress Sox3 (K). Sox3-positive cells appear mainly in the deep hilus between BrdU-positive cell clusters closer to the granule cell layer (gcl) at P2 (I). Sox3 expression appears more restricted to the SGZ at P14 (J) and especially in the adult (K). Scale bar $=75$ $\mu \mathrm{m}$ in $\mathrm{H}$ (applies to A,C,D-F,H); $125 \mu \mathrm{m}$ for B,G,I,J; $50 \mu \mathrm{m}$ for $\mathrm{D}^{\prime}-\mathrm{F}^{\prime}$; $60 \mu \mathrm{m}$ for $\mathrm{K} ; 30 \mu \mathrm{m}$ for insets in $\mathrm{K}$.

positive cells (Fig. 5D,E). In the subependymal zone of the olfactory bulb, $38 \%$ of Sox3-immunoreactive cells were doubly labeled for $\beta$-tubulin (Fig. 5G), and some were also PSA-NCAM-positive (Fig. 5F). Almost 30\% of Sox3labeled cells in the granular layer were immunoreactive for the mature neuronal marker NeuN (Fig. 5H). These findings indicate that Sox3 is transiently expressed by SVZ neural stem cells and their undifferentiated progeny in the SVZ-olfactory bulb pathway, and then expression is turned off as the cells differentiate into olfactory granular layer neurons.

\section{Sox3 expression during adult dentate granule cell neurogenesis}

We next examined the phenotypes of Sox3-positive cells in the adult mouse SGZ with double-label immunofluorescence for Sox3 and cell-type-specific markers. Subpopulations of Sox3-positive cells in the SGZ frequently ex-

pressed neuroblast markers, such as PSA-NCAM (Fig. 6A,B), $\beta$-tubulin (33\%, Fig. 6D-G), and calretinin (22\%, Fig. 6C). By contrast, relatively few expressed the more mature neuronal marker NeuN (9\%, Fig. 6H-J). Nearly half of the Sox3-immunoreactive cells coexpressed GFAP (48\%, Fig. 6K-M). Many of these Sox3/GFAP doublelabeled cells appeared to have a radial glial-like morphology, suggesting that they were SGZ progenitor cells (Seri et al., 2001, 2004). Consistent with this idea, we found similar cells with radial glial morphology that coexpressed Sox3 and nestin in the dentate gyrus (data not shown). These results, combined with the pulse-chase BrdU labeling data described above (Fig. 4), provide strong evidence that neural progenitor cells and differentiating neuroblasts in the dentate SGZ express Sox3 and that this expression declines as the cells differentiate into dentate granule neurons. 

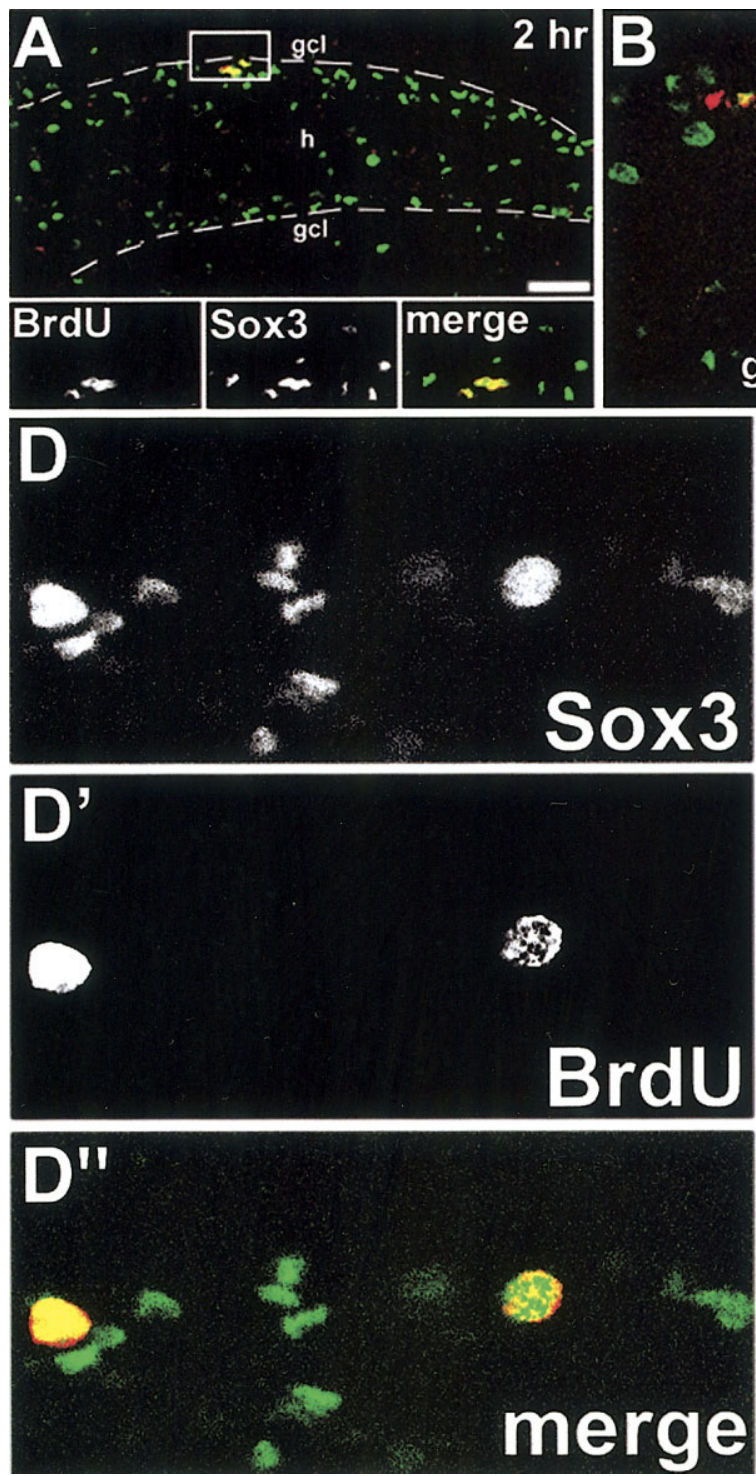

Fig. 4. Confocal images of coronal brain sections through the adult mouse dentate gyrus after immunofluorescence double labeling for Sox3 (green in all panels) and BrdU (red in all panels). A,D-D"': At 2 hours after BrdU injection, all BrdU-labeled cells express Sox3. B,C,E-E': By 4 days after BrdU injection, only a small proportion of

Because other Sox proteins exist in the SoxB1 subfamily, we also analyzed the locations and phenotypes of Sox2-immunoreactive cells in the adult mouse SVZ and dentate gyrus by using antibodies for Sox2 (Ferri et al., 2004; Komitova and Eriksson, 2004) and cell-typespecific markers. We found that the vast majority of Sox2-positive cells in the dentate gyrus were located in the SGZ and coexpressed GFAP (79\%, Fig. 6N); smaller proportions of Sox2-immunoreactive cells in the SGZ expressed the neuroblast markers PSA-NCAM (31\%), neuron-specific $\beta$-tubulin (21\%), or calretinin (23\%, Fig. 60 , and data not shown). No Sox2-labeled cells coexpressed NeuN (data not shown). In the SVZ, most Sox2positive cells showed GFAP immunoreactivity, and a smaller number coexpressed $\beta$-tubulin (data not
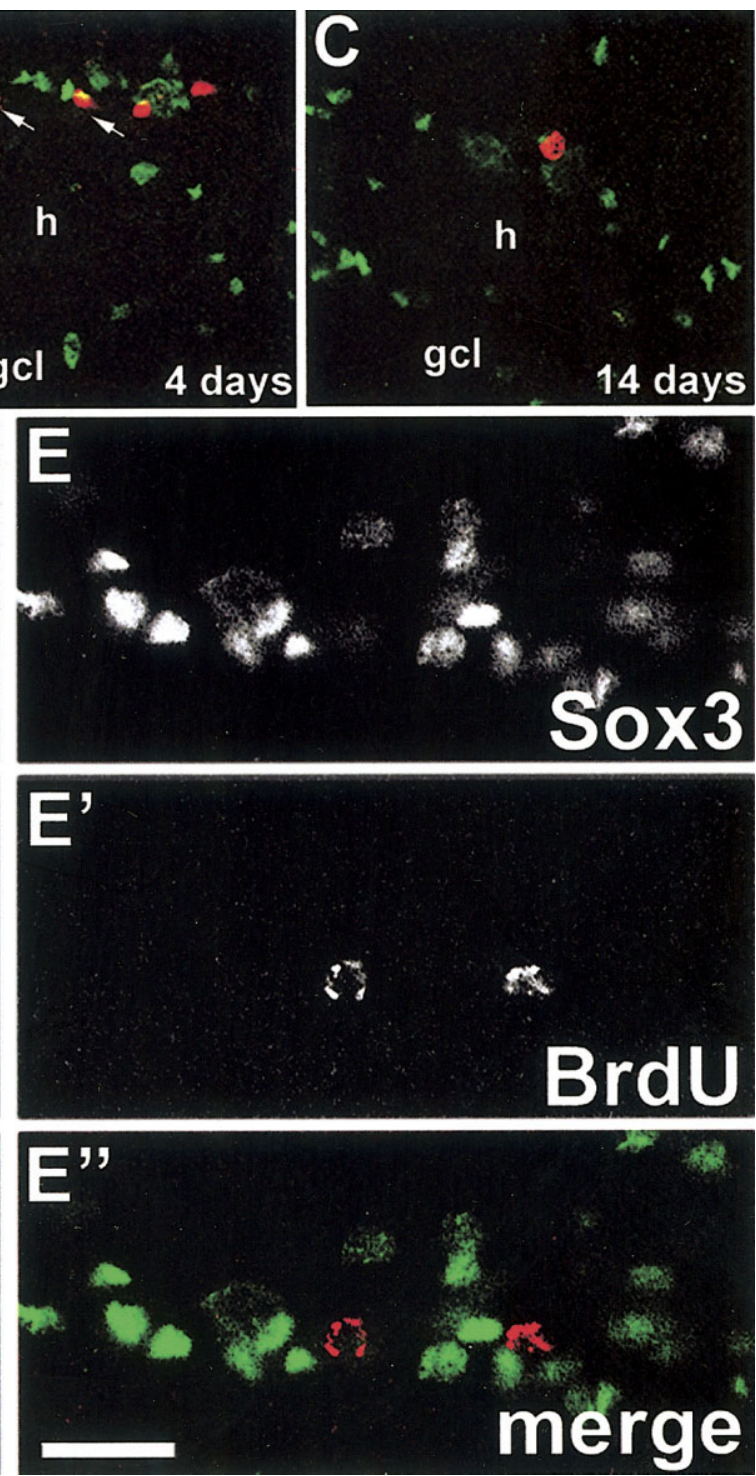

BrdU-positive cells maintains Sox3 expression (arrows in B), and, by 14 days, BrdU-positive cells no longer express Sox3 (C,E-E' ${ }^{\prime \prime}$. gcl, Granule cell layer; h, hilus. Scale bars $=50 \mu \mathrm{m}$ in A; $30 \mu \mathrm{m}$ for insets in $\mathrm{A} ; 25 \mu \mathrm{m}$ in $\mathrm{E}^{\prime \prime}$ (apllies to D-E"'); $50 \mu \mathrm{m}$ for B,C.

shown). These findings suggest that, like Sox3, Sox2 is expressed by neural progenitors and immature neurons and is rapidly down-regulated with differentiation. In addition, Sox2 expression patterns are shifted to more immature cells than Sox3, with greater percentages of GFAP-labeled progenitor-like cells and fewer differentiated neurons expressing Sox2.

\section{Sox3 expression in neural stem cells derived from postnatal mouse SVZ and hESCs}

To examine the temporal pattern of Sox3 expression during neuronal differentiation, we took advantage of well-defined in vitro methods for culturing neural stem 

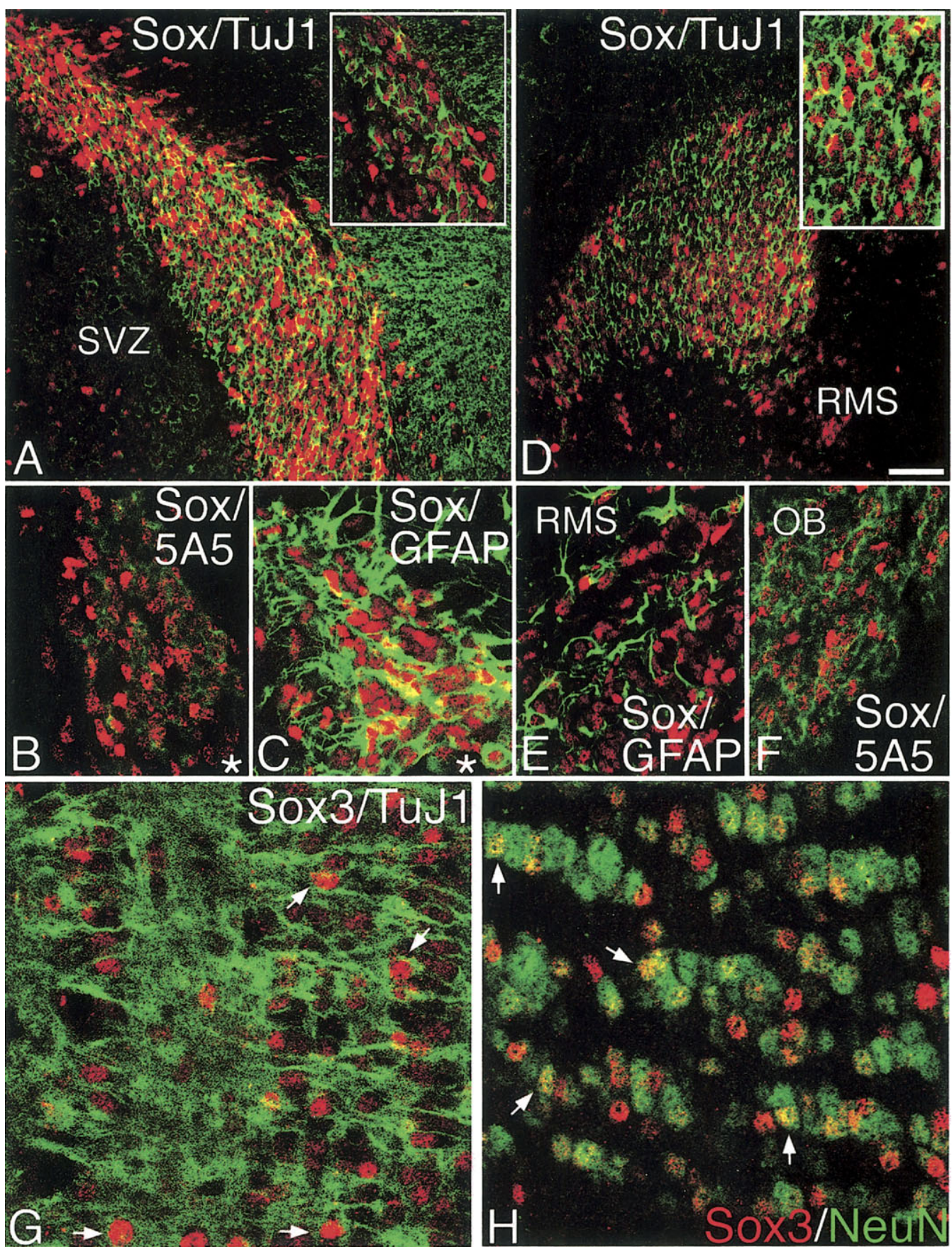

Fig. 5. Confocal optical sections of adult mouse SVZ-olfactory bulb pathway after immunofluorescence double labeling for Sox3 (red in all panels) and cell type-specific markers (green in all panels). A,D: Double labeling for Sox3 and TuJ1 in SVZ (A) and RMS (D). Many Sox3-positive cells are TuJ1-positive. B,F: Some Sox3immunolabled cells coexpress PSA-NCAM (5A5) in the SVZ (B) and olfactory bulb (OB; F). C,E: In dorsolateral SVZ (C) and RMS (E), clusters of Sox3-positive cells are surrounded by GFAP-positive cells. A portion is doubly labeled. G: In the olfactory subependyma, under half of the Sox3-immunoreactive cells coexpress TuJ1 (arrows). H: About one-third of the Sox3-labeled cells in the olfactory granule cell layer express the mature neuronal marker NeuN (arrows). Asterisk, lateral ventricle. Scale bar $=50 \mu \mathrm{m}$ in D (applies to A,D); $40 \mu \mathrm{m}$ for B,C,E,F, insets in A,D; $25 \mu \mathrm{m}$ for G,H. cells from postnatal mouse SVZ and hESCs (Reynolds and Weiss, 1992; Thomson et al., 1998; Zhang et al., 2001). SVZ cells from P15 mouse were expanded as neurospheres in the presence of bFGF and EGF. Cultures were fixed without differentiation and labeled with antibodies against Sox3 and the neural progenitor marker nestin. Most cells in the undifferentiated neurospheres expressed both Sox3 and nestin (Fig. 7A-C). In subsequent experi- 

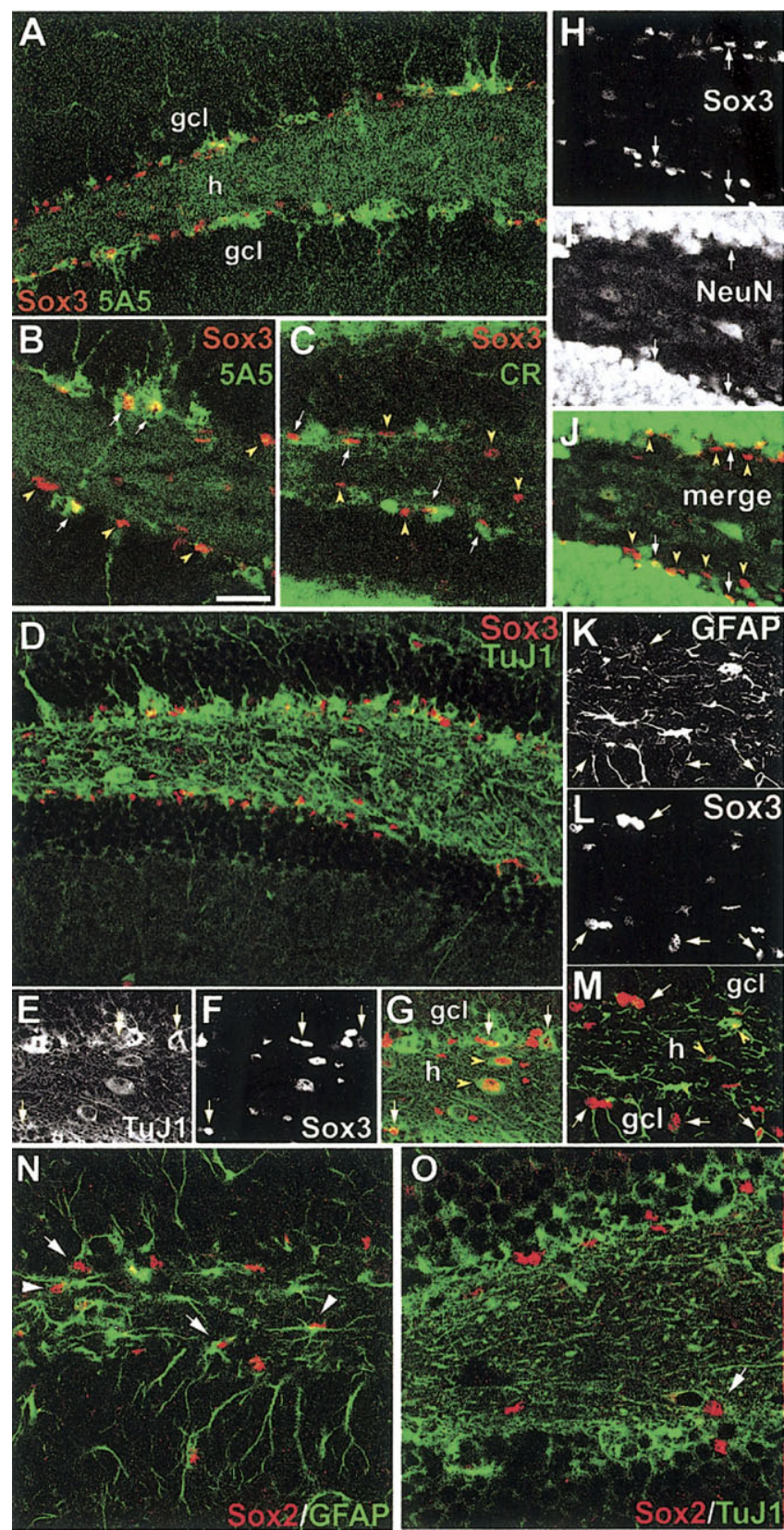

Fig. 6. Double-label immunofluorescence for Sox3 or Sox2 and cell phenotype markers in the adult mouse dentate gyrus. All panels show confocal coronal images with Sox3 and Sox2 in red. A,B: Most Sox3immunoreactive cells appear in the SGZ, and a subset coexpresses the neuroblast marker PSA-NCAM (5A5). C: Some Sox3-immunoreactive cells also express calretinin. Arrows show double-labeled cells, and arrowheads denote single-labeled, Sox3-positive cells. D-G: About one-third of Sox3-labeled cells coexpresses the "immature" neuronal marker $\beta$-tubulin ( $\mathrm{TuJ} 1$; arrows). Arrowheads in $\mathrm{G}$ denote putative mature hilar cells that express both Sox-3 and $\beta$-tubulin. H-J: Few Sox3-positive cells coexpress the mature neuronal marker NeuN (arrows), but most are NeuN negative (arrowheads). K-M: Nearly half of the Sox3-immunolabeled cells also are immunoreactive for GFAP and display a radial glial-like progenitor cell (arrows) or more mature astrocytic (arrowheads) morphology. N,O: Most Sox2-positive cells express GFAP and show a radial glial-like morphology (arrows), although some Sox2/GFAP double-labeled cells have a more mature astrocytic morphology (arrowheads). A subset of Sox2-positive cells labels with the TuJ1 antibody (arrow). Scale bar $=50 \mu \mathrm{m}$ for A; $25 \mu \mathrm{m}$ in B (applies to B,C,E-O); $60 \mu \mathrm{m}$ for D. ments, we dissociated the primary neurospheres and differentiated them for 4 hours, 2 days, or 8 days to determine the temporal pattern of Sox3 expression during neural differentiation. Cultures were fixed and immunostained for Sox3 and cell-type-specific markers. After only a 4-hour differentiation to let cells adhere to the tissue culture dish, nearly all the cells expressed Sox3, and no neurons or glia were present (Fig. 7D, and data not shown). Cultures differentiated for 2 days showed slightly decreased Sox3 immunoreactivity, and a few $\beta$-tubulinimmunoreactive neurons and GFAP-immunoreactive astrocytes were detected (Fig. 7E,F). Few Sox3-positive cells coexpressed GFAP (Fig. 7E), and none coexpressed $\beta$-tubulin (Fig. 7F). After 8 days, Sox3 expression diminished markedly and more astrocytes and neurons appeared. Some of the astrocytes expressed very low levels of Sox3 (Fig. 7G), but no Sox3/ $\beta$-tubulin doubled-labeled cells were found (Fig. 7H).

We next explored neurospheres derived from hESCs. The NIH-approved H-1 hESC clone was cultured on irradiated MEFS and then differentiated into a neural lineage. Prior to differentiation, hESCs showed immunoreactivity for Oct3/4 and Sox2, but not Sox3 (data not shown). After neural differentiation, Sox3 immunoreactivity appeared in many cells located more centrally within the neurospheres, whereas $\beta$-tubulin-positive neurons were found more peripherally, and few expressed Sox3 (Fig. 7I, and data not shown). Consistent with the in vivo data described above, these findings suggest that postnatal mouse SVZ and hESC-derived neural progenitors express Sox3 and that both cell types turn off expression as they undergo differentiation into neurons or astrocytes.

\section{DISCUSSION}

Our results indicate that Sox3 protein expression persists in the neonatal and adult mouse forebrain SVZ, RMS, olfactory bulb, and SGZ. A subset of Sox3-positive cells in the SVZ and SGZ actively proliferates in the neonate, and the proportion increases markedly in adulthood. Many Sox3-immunoreactive cells in the adult SVZ and SGZ appear to be radial glia-like, GFAP-positive stem/ progenitor cells, whereas others coexpress immature neuronal markers consistent with transit-amplifying progenitor or neuroblast phenotypes. In mouse SVZ or hESCderived neurospheres, most cells initially express Sox3 and then down-regulate expression during differentiation. This constellation of findings supports a role for Sox3 in mammalian forebrain neural stem/progenitor cell function throughout life. The lower level of Sox3 expression seen in specific nonneurogenic regions of the adult mouse brain suggests that this protein also maintains nondevelopmental functions, the nature of which remains to be determined.

\section{Anti-Sox3 antibody recognizes Sox3 in neural progenitor cells}

Interpretation of immunohistochemical data largely depends on antibody specificity. Although our anti-Sox3 antibody was raised in Xenopus, Western blots suggest that it recognizes a band of the appropriate size for Sox3 in zebrafish, mouse, and human brain. Although the antibody yields a second band when reacted with human brain that is closest to human Sox2 in size, albeit slightly 

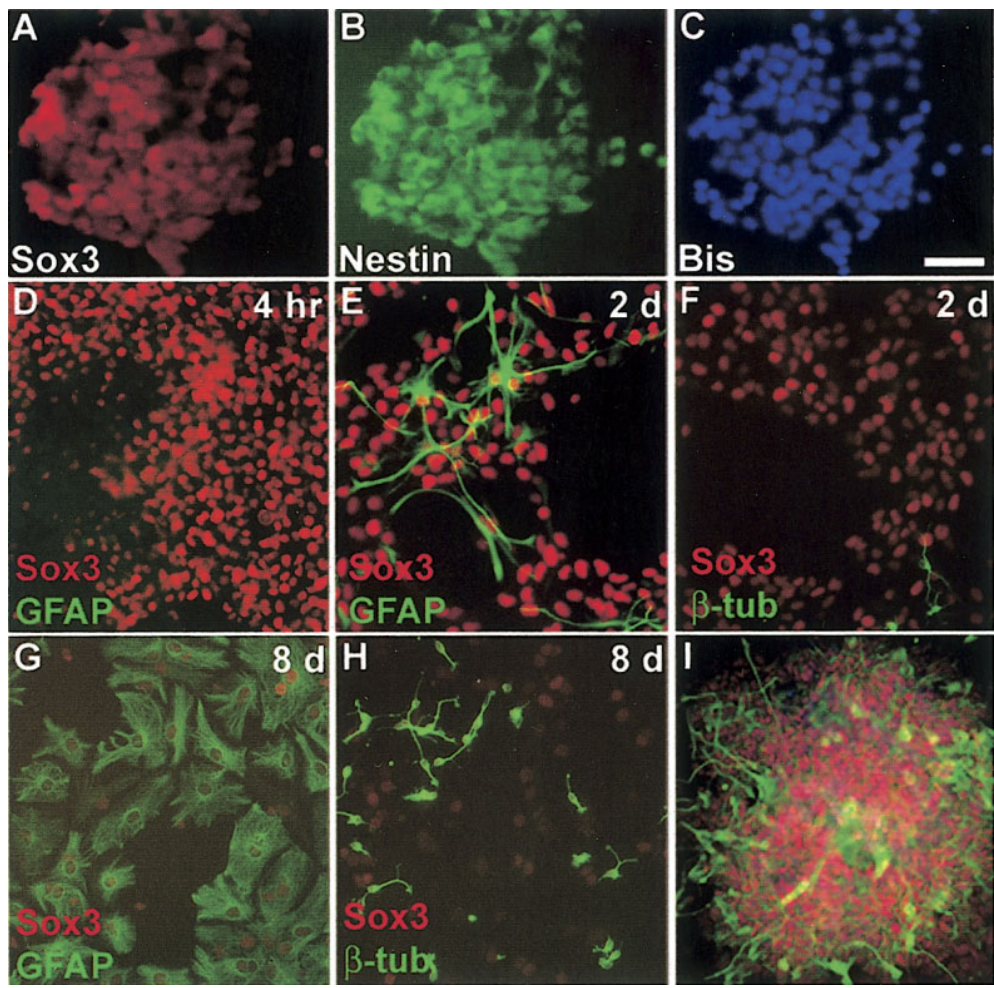

Fig. 7. Sox3 expression in neurospheres derived from $\mathrm{P} 15$ mouse SVZ (A-H) or the H1 hESC clone (I). A-C: Cells in undifferentiated neurospheres express Sox3 (A) and the neural progenitor marker nestin (B). Neurospheres were counterstained with bisbenzimide (Bis). D-H: Sox3 (red) and GFAP (green) or $\beta$-tubulin ( $\beta$-tub; green) double immunostaining. In neurospheres differentiated for 4 hours, only Sox3-positive cells are present, and no GFAP immunoreactivity is present (D). After a 2-day differentiation, few Sox3/GFAP double- labeled cells are found (E). Very few $\beta$-tubulin-immunoreactive neurons appear, and they do not express Sox3 (F). G,H: After 8 days, Sox 3 expression decreases markedly, but some cells remain Sox3 and GFAP doubly labeled (G). Again, Sox3 is not expressed by $\beta$-tubulinpositive neurons (H). I: hESC-derived neurospheres express Sox3 centrally and $\beta$-tubulin in cells on the periphery, with minimal colocalization. Scale bar $=50 \mu \mathrm{m}$ in $\mathrm{C}$ (applies to A-H); $100 \mu \mathrm{m}$ for I. smaller, several pieces of evidence suggest that the antibody does not detect Sox2 by immunohistochemistry. First, undifferentiated hESCs are known to express Sox2 and not Sox3 (Stevanovic, 2003; Ginis et al., 2004; Boyer et al., 2005; Stromberg and Parent, unpublished results), whereas both proteins are expressed after neural differentiation. We confirmed these findings by immunocytochemistry with our Sox3 and a commercial Sox2 antibody. Second, the immunoreactivity pattern of Sox3 and Sox2 in mouse, although similar, did not completely overlap. In the adult mouse dentate gyrus, for example, no NeuNpositive cells expressed Sox 2 , but nearly $10 \%$ coexpressed NeuN and Sox3. The possibility that the antibody recognizes Sox1 in addition to Sox3 is unlikely based on the Western blot data but cannot be excluded entirely at present; obtaining Sox3 null mouse tissue for immunohistochemistry will eventually clarify this issue.

The Sox B1 subfamily (Sox1-3) proteins are expressed by the embryonic neuroepithelium (Collignon et al., 1996). In terms of later expression, recent studies indicate that almost all newly divided cells in the SVZ and SGZ express Sox2, and some of these Sox2-positive cells coexpress GFAP and display a radial glia-like morphology (Ferri et al., 2004; Komitova and Eriksson, 2004). Some weakly labeled Sox2-immunoreactive cells in the RMS also are immunoreactive for PSA-NCAM (Ferri et al., 2004). We found similar Sox2 expression patterns in the adult, and Sox3 immunoreactivity appeared in an overlapping but not identical pattern. Two hours after a BrdU pulse, almost all of the BrdU-labeled cells in the adult SVZ and SGZ expressed Sox3. Type B cells in the SVZ and radial glia-like cells in the SGZ that express GFAP are considered to be neural stem-like cells (Doetsch et al., 1999; Seri et al., 2001). In the SGZ, nearly half of the Sox3immunoreactive cells coexpressed GFAP and displayed a radial glia-like morphology, as did many in the SVZ. A subpopulation of Sox3-positive cells in the SVZ and SGZ also expressed the neuroblast marker PSA-NCAM or $\beta$-tubulin. A few NeuN-positive cells in the OB and dentate gyrus still maintained Sox3 expression, but Sox3 immunoreactivity was absent in most differentiated neurons in these regions. Taken together, these findings suggest that Sox3 is expressed mainly by primary progenitors, transit-amplifying cells, and neuroblasts.

Further support for the neural progenitor cell nature and temporal pattern of Sox3 expression derives from our in vitro studies. Most cells in undifferentiated mouse SVZ neurospheres initially express Sox3 and then downregulate expression during differentiation. Similarly, most neural progenitors but few differentiating neurons derived from hESCs show Sox3 immunoreactivity. These data therefore provide strong evidence that Sox3 is ex- 
pressed by neural progenitor cells and transiently by their newly generated neuronal progeny in mice and humans.

\section{Ontogeny of Sox3 in postnatal SVZ and SGZ}

In the mouse embryo, Sox3 is expressed in the primitive ectoderm, epiblast, and neuroepithelium (Collignon et al., 1996; Wood and Episkopou, 1999), but little is known about its postnatal expression. We find that Sox3 is present in postnatal neurogenic regions as early as P2 and persists into adulthood. Sox3 expression in the neonatal dentate gyrus and SVZ shows much less overlap with dividing (BrdU-labeled) cells 2 hours after a single pulse BrdU injection than in the adult. In the neonatal SVZ and RMS, Sox3 is expressed closer to the ventricle than the BrdU-positive cells. BrdU- and Sox3-postive cells in the P2 dentate gyrus appear in largely nonoverlapping populations scattered in the hilus, and over time Sox3 expression becomes established in the SGZ tertiary matrix (Altman and Bayer, 1990a,b; Li and Pleasure, 2005).

The pattern of Sox3 immunoreactivity relative to proliferating cells at early postnatal ages, with Sox3 closer to the ventricle in the ventral SVZ and scattered in the dentate hilus, suggests that this marker labels a relatively quiescent progenitor population. This result also fits with reports that primary neural progenitors in the adult appear to be more proliferative than at younger ages, especially in the dentate gyrus (Doetsch et al., 1999; Seri et al., 2001). The most plausible explanation for this finding is that Sox3 is expressed in transit-amplifying cells and neuroblasts in the adult much more than in the neonate. Less likely is that increases in cell cycle time of forebrain neural progenitors known to occur with age contribute to the differences (Lewis, 1978; Schultze and Korr, 1981; Smith and Luskin, 1998; Calegari et al., 2005); however, the degree of cell cycle lengthening in the adult (33\% increase in cell cycle duration between P2 and adult) is relatively small and restricted to the $G_{1}$ phase and, therefore, is unlikely to account for the large differences we observed between the BrdU labeling index of Sox3-expressing cells in neonatal vs. adult mice. Because of the heterogeneous nature of in situ SVZ and SGZ progenitors and the paucity of reports comparing their cell compositions and cell cycle times at different ages, the complexity precludes definitive conclusions regarding the contribution of cell cycle alterations.

In the adult SVZ and SGZ, newly divided cells are Sox3 positive and turn off Sox3 expression within 2 weeks. Intriguingly, nearly all of the BrdU-labeled cells that persist in the ventral SVZ continue to express Sox3 for at least 14 days after BrdU incorporation. These cells therefore may represent the relatively quiescent neural stem cell population. This idea is supported by the recent finding that quiescent adult SVZ stem cells are located primarily in the ventral aspect of the SVZ (Ahn and Joyner, 2005). Thus, Sox3 appears to be expressed by more immature, quiescent neural progenitor cells in the neonatal forebrain, but a portion of the Sox3-positive cells in the ventral SVZ of the adult may be stem cells.

\section{Potential Sox3 functions in postnatal neurogenic and nonneurogenic brain regions}

Specific roles for Sox3 in development are only beginning to be defined. Studies of Sox3 null mice indicate that it is required for proper formation of the hypothalamic- pituitary axis (Rizzoti et al., 2004). Sox3-deficient mice also have craniofacial abnormalities and defects in CNS midline structures (Rizzoti et al., 2004). Our finding that Sox3 is expressed by GFAP- and $\beta$-tubulin-positive, BrdUlabeled cells in the adult SVZ and SGZ suggests that it may continue to regulate proliferation, survival, or differentiation of neural progenitor cells throughout life. Supporting this idea are recent data indicating that deficiency of the closely related SoxB1 family gene Sox2 leads to decreased BrdU- and GFAP-positive cell numbers in the adult SVZ and SGZ (Ferri et al., 2004). In addition, we found that Sox3 colocalizes with cells expressing the intermediate filament protein nestin, which is a marker for most neural progenitor cells from embryonic ages to adulthood. Recently, the neural enhancer region of nestin has been found to contain a binding site for Sox B1 proteins (Tanaka et al., 2004). These findings together suggest that Sox B1 proteins play important roles in maintaining neural progenitors.

Both our anti-Sox3 antibody and the commercial antiSox2 antibody that we used were raised in rabbits, excluding a direct comparison of the two proteins by double labeling. We found, however, that Sox3- and Sox2immunoreactive cell populations were very similar but did not completely overlap in the adult, with Sox3 found in slightly more differentiated neural progenitors. These similar transcription factors therefore may have subtly different effects on neural progenitor development in the rodent. In chick spinal cord, Sox1-3 maintain neural progenitor cells in an undifferentiated state by counteracting the activity of proneural proteins (Bylund et al., 2003). Sox3 down-regulation upon neuronal differentiation in adult rodent olfactory bulb and dentate gyrus is consistent with a similar role.

We found that Sox3 also is expressed in certain nonneurogenic regions of the neonatal and adult mouse brain. These areas include the olfactory tubercle, dorsolateral septum, cerebellar Purkinje cell layer, lateral habenular nucleus, and ventromedial hypothalamus. Weaker Sox3 immunoreactivity appears in scattered pyramidal cells of the cerebral cortex and in striatal and thalamic neurons, similar to the pattern recently described for Sox2 (Ferri et al., 2004). Although some Sox3-immunoreactive cells in nonneurogenic zones may be quiescent or cycling neural progenitors known to exist throughout the brain parenchyma (Palmer et al., 1999; Gensert and Goldman, 2001), the large numbers and discrete organization suggest that most are mature neurons. Some interneuron-like cells in the hippocampal dentate gyrus also express Sox3, occasionally in a cytoplasmic rather than nuclear pattern. Similar patterns of persistent expression in differentiated neurons and altered cellular localization in the adult have been described for other transcription factors involved in neural development, such as basic helix-loop-helix and homeobox proteins, including Olig1/2 and Otx1; however, specific roles for these proteins in the adult have not been determined (Elliott et al., 2001; Zhang et al., 2002; Samanta and Kessler, 2004). Experiments to manipulate Sox3 expression at different ages and in specific cell types will no doubt shed light on both developmental and maintenance functions of this protein in the postnatal mammalian brain. 


\section{ACKNOWLEDGMENTS}

We thank Dr. Sue O'Shea and the University of Michigan Human Embryonic Stem Cell Center for assistance with hESC cultures and Dr. Eva Feldman for providing human brain samples.

\section{LITERATURE CITED}

Ahn S, Joyner AL. 2005. In vivo analysis of quiescent adult neural stem cells responding to Sonic hedgehog. Nature 437:894-897.

Altman J. 1969a. Autoradiographic and histological studies of postnatal neurogenesis. 3. Dating the time of production and onset of differentiation of cerebellar microneurons in rats. J Comp Neurol 136:269-293.

Altman J. 1969b. Autoradiographic and histological studies of postnatal neurogenesis. IV. Cell proliferation and migration in the anterior forebrain, with special reference to persisting neurogenesis in the olfactory bulb. J Comp Neurol 137:433-457.

Altman J, Bayer SA. 1990a. Migration and distribution of two populations of hippocampal granule cell precursors during the perinatal and postnatal periods. J Comp Neurol 301:365-381.

Altman J, Bayer SA. 1990b. Mosaic organization of the hippocampal neuroepithelium and the multiple germinal sources of dentate granule cells. J Comp Neurol 301:325-342.

Altman J, Das GD. 1965. Autoradiographic and histological evidence of postnatal hippocampal neurogenesis in rats. J Comp Neurol 124:319335 .

Belluzzi O, Benedusi M, Ackman J, LoTurco JJ. 2003. Electrophysiological differentiation of new neurons in the olfactory bulb. J Neurosci 23 : 10411-10418.

Boyer LA, Lee TI, Cole MF, Johnstone SE, Levine SS, Zucker JP, Guenther MG, Kumar RM, Murray HL, Jenner RG, Gifford DK, Melton DA Jaenisch R, Young RA. 2005. Core transcriptional regulatory circuitry in human embryonic stem cells. Cell 122:947-956.

Brandt MD, Jessberger S, Steiner B, Kronenberg G, Reuter K, Bick-Sander A, von der Behrens W, Kempermann G. 2003. Transient calretinin expression defines early postmitotic step of neuronal differentiation in adult hippocampal neurogenesis of mice. Mol Cell Neurosci 24:603613.

Bylund M, Andersson E, Novitch BG, Muhr J. 2003. Vertebrate neurogenesis is counteracted by Sox1-3 activity. Nat Neurosci 6:1162-1168.

Calegari F, Haubensak W, Haffner C, Huttner WB. 2005. Selective lengthening of the cell cycle in the neurogenic subpopulation of neural progenitor cells during mouse brain development. J Neurosci 25:65336538.

Cameron HA, Woolley CS, McEwen BS, Gould E. 1993. Differentiation of newly born neurons and glia in the dentate gyrus of the adult rat. Neuroscience 56:337-344.

Carlen M, Cassidy RM, Brismar H, Smith GA, Enquist LW, Frisen J. 2002. Functional integration of adult-born neurons. Curr Biol 12:606-608.

Collignon J, Sockanathan S, Hacker A, Cohen-Tannoudji M, Norris D, Rastan S, Stevanovic M, Goodfellow PN, Lovell-Badge R. 1996. A comparison of the properties of Sox-3 with Sry and two related genes, Sox-1 and Sox-2. Development 122:509-520.

Corotto FS, Henegar JR, Maruniak JA. 1994. Odor deprivation leads to reduced neurogenesis and reduced neuronal survival in the olfactory bulb of the adult mouse. Neuroscience 61:739-744.

Craig CG, Tropepe V, Morshead CM, Reynolds BA, Weiss S, van der Kooy D. 1996. In vivo growth factor expansion of endogenous subependyma neural precursor cell populations in the adult mouse brain. J Neurosci 16:2649-2658

Dodd J, Morton SB, Karagogeos D, Yamamoto M, Jessell TM. 1988. Spatial regulation of axonal glycoprotein expression on subsets of embryonic spinal neurons. Neuron 1:105-116.

Doetsch F, Garcia-Verdugo JM, Alvarez-Buylla A. 1997. Cellular composition and three-dimensional organization of the subventricular germinal zone in the adult mammalian brain. J Neurosci 17:5046-5061.

Doetsch F, Caille I, Lim DA, Garcia-Verdugo JM, Alvarez-Buylla A. 1999. Subventricular zone astrocytes are neural stem cells in the adult mammalian brain. Cell 97:703-716.

Elliott RC, Khademi S, Pleasure SJ, Parent JM, Lowenstein DH. 2001. Differential regulation of basic helix-loop-helix mRNAs in the dentate gyrus following status epilepticus. Neuroscience 106:79-88.

Eriksson PS, Perfilieva E, Bjork-Eriksson T, Alborn AM, Nordborg C,
Peterson DA, Gage FH. 1998. Neurogenesis in the adult human hippocampus. Nat Med 4:1313-1317.

Ferri AL, Cavallaro M, Braida D, Di Cristofano A, Canta A, Vezzani A, Ottolenghi S, Pandolfi PP, Sala M, DeBiasi S, Nicolis SK. 2004. Sox2 deficiency causes neurodegeneration and impaired neurogenesis in the adult mouse brain. Development 131:3805-3819.

Gensert JM, Goldman JE. 2001. Heterogeneity of cycling glial progenitors in the adult mammalian cortex and white matter. J Neurobiol 48:7586.

Gheusi G, Cremer H, McLean H, Chazal G, Vincent JD, Lledo PM. 2000. Importance of newly generated neurons in the adult olfactory bulb for odor discrimination. Proc Natl Acad Sci U S A 97:1823-1828.

Ginis I, Luo Y, Miura T, Thies S, Brandenberger R, Gerecht-Nir S, Amit M, Hoke A, Carpenter MK, Itskovitz-Eldor J, Rao MS. 2004. Differences between human and mouse embryonic stem cells. Dev Biol 269:360 380 .

Gleeson JG, Lin PT, Flanagan LA, Walsh CA. 1999. Doublecortin is a microtubule-associated protein and is expressed widely by migrating neurons. Neuron 23:257-271.

Gould E, Beylin A, Tanapat P, Reeves A, Shors TJ. 1999. Learning enhances adult neurogenesis in the hippocampal formation. Nat Neurosci $2: 260-265$.

Graham V, Khudyakov J, Ellis P, Pevny L. 2003. SOX2 functions to maintain neural progenitor identity. Neuron 39:749-765.

Gritti A, Parati EA, Cova L, Frolichsthal P, Galli R, Wanke E, Faravelli L, Morassutti DJ, Roisen F, Nickel DD, Vescovi AL. 1996. Multipotential stem cells from the adult mouse brain proliferate and self-renew in response to basic fibroblast growth factor. J Neurosci 16:1091-1100.

Hockfield S, McKay RD. 1985. Identification of major cell classes in the developing mammalian nervous system. J Neurosci 5:3310-3328.

Huang H, Paliouras M, Rambaldi I, Lasko P, Featherstone M. 2003. Nonmuscle myosin promotes cytoplasmic localization of PBX. Mol Cell Biol 23:3636-3645.

Karsten SL, Kudo LC, Jackson R, Sabatti C, Kornblum HI, Geschwind DH 2003. Global analysis of gene expression in neural progenitors reveals specific cell-cycle, signaling, and metabolic networks. Dev Biol 261 : 165-182.

Kempermann G, Kuhn HG, Gage FH. 1997. More hippocampal neurons in adult mice living in an enriched environment. Nature 386:493-495.

Komitova M, Eriksson PS. 2004. Sox-2 is expressed by neural progenitors and astroglia in the adult rat brain. Neurosci Lett 369:24-27.

Kuhn HG, Dickinson-Anson H, Gage FH. 1996. Neurogenesis in the dentate gyrus of the adult rat: age-related decrease of neuronal progenitor proliferation. J Neurosci 16:2027-2033.

Kuhn HG, Winkler J, Kempermann G, Thal LJ, Gage FH. 1997. Epiderma growth factor and fibroblast growth factor-2 have different effects on neural progenitors in the adult rat brain. J Neurosci 17:5820-5829.

Latov N, Nilaver G, Zimmerman EA, Johnson WG, Silverman AJ, Defendini R, Cote L. 1979. Fibrillary astrocytes proliferate in response to brain injury: a study combining immunoperoxidase technique for glial fibrillary acidic protein and radioautography of tritiated thymidine. Dev Biol 72:381-384

Laumonnier F, Ronce N, Hamel BC, Thomas P, Lespinasse J, Raynaud M Paringaux C, Van Bokhoven H, Kalscheuer V, Fryns JP, Chelly J, Moraine C, Briault S. 2002. Transcription factor SOX3 is involved in $\mathrm{X}$-linked mental retardation with growth hormone deficiency. Am J Hum Genet 71:1450-1455.

Lee MK, Rebhun LI, Frankfurter A. 1990. Posttranslational modification of class III beta-tubulin. Proc Natl Acad Sci U S A 87:7195-7199.

Lewis PD. 1978. Kinetics of cell proliferation in the postnatal rat dentate gyrus. Neuropathol Appl Neurobiol 4:191-195.

Li G, Pleasure SJ. 2005. Morphogenesis of the dentate gyrus: what we are learning from mouse mutants. Dev Neurosci 27:93-99.

Lois C, Alvarez-Buylla A. 1994. Long-distance neuronal migration in the adult mammalian brain. Science 264:1145-1148.

Luskin MB. 1993. Restricted proliferation and migration of postnatally generated neurons derived from the forebrain subventricular zone. Neuron 11:173-189.

Luskin MB. 1998. Neuroblasts of the postnatal mammalian forebrain: their phenotype and fate. J Neurobiol 36:221-233.

Malas S, Duthie SM, Mohri F, Lovell-Badge R, Episkopou V. 1997. Cloning and mapping of the human SOX1: a highly conserved gene expressed in the developing brain. Mamm Genome 8:866-868. 
Mullen RJ, Buck CR, Smith AM. 1992. NeuN, a neuronal specific nuclear protein in vertebrates. Development 116:201-211.

Nunzi MG, Birnstiel S, Bhattacharyya BJ, Slater NT, Mugnaini E. 2001. Unipolar brush cells form a glutamatergic projection system within the mouse cerebellar cortex. J Comp Neurol 434:329-341.

Palmer TD, Markakis EA, Willhoite AR, Safar F, Gage FH. 1999. Fibroblast growth factor-2 activates a latent neurogenic program in neural stem cells from diverse regions of the adult CNS. J Neurosci 19:84878497.

Peretto P, Merighi A, Fasolo A, Bonfanti L. 1997. Glial tubes in the rostral migratory stream of the adult rat. Brain Res Bull 42:9-21.

Pevny LH, Lovell-Badge R. 1997. Sox genes find their feet. Curr Opin Genet Dev 7:338-344.

Pevny L, Rao MS. 2003. The stem-cell menagerie. Trends Neurosci 26:351359.

Reynolds BA, Weiss S. 1992. Generation of neurons and astrocytes from isolated cells of the adult mammalian central nervous system. Science 255:1707-1710.

Rizzoti K, Brunelli S, Carmignac D, Thomas PQ, Robinson IC, LovellBadge R. 2004. SOX3 is required during the formation of the hypothalamo-pituitary axis. Nat Genet 36:247-255.

Rochefort C, Gheusi G, Vincent JD, Lledo PM. 2002. Enriched odor exposure increases the number of newborn neurons in the adult olfactory bulb and improves odor memory. J Neurosci 22:2679-2689.

Samanta J, Kessler JA. 2004. Interactions between ID and OLIG proteins mediate the inhibitory effects of BMP4 on oligodendroglial differentiation. Development 131:4131-4142.

Schultze B, Korr H. 1981. Cell kinetic studies of different cell types in the developing and adult brain of the rat and the mouse: a review. Cell Tissue Kinet 14:309-325.

Seaberg RM, van der Kooy D. 2002. Adult rodent neurogenic regions: the ventricular subependyma contains neural stem cells, but the dentate gyrus contains restricted progenitors. J Neurosci 22:1784-1793.

Seri B, Garcia-Verdugo JM, McEwen BS, Alvarez-Buylla A. 2001. Astrocytes give rise to new neurons in the adult mammalian hippocampus. J Neurosci 21:7153-7160.

Shen H, Watanabe M, Tomasiewicz H, Rutishauser U, Magnuson T, Glass DJ. 1997. Role of neural cell adhesion molecule and polysialic acid in mouse circadian clock function. J Comp Neurol 17:5221-5229.

Shors TJ, Miesegaes G, Beylin A, Zhao M, Rydel T, Gould E. 2001. Neurogenesis in the adult is involved in the formation of trace memories. Nature 410:372-376.

Smith CM, Luskin MB. 1998. Cell cycle length of olfactory bulb neuronal progenitors in the rostral migratory stream. Dev Dyn 213:220-227.

Song H, Stevens CF, Gage FH. 2002. Astroglia induce neurogenesis from adult neural stem cells. Nature 417:39-44.
Stevanovic M. 2003. Modulation of SOX2 and SOX3 gene expression during differentiation of human neuronal precursor cell line NTERA2. Mol Biol Rep 30:127-132.

Stevanovic M, Lovell-Badge R, Collignon J, Goodfellow PN. 1993. SOX3 is an X-linked gene related to SRY. Hum Mol Genet 2:2013-2018.

Stevanovic M, Zuffardi O, Collignon J, Lovell-Badge R, Goodfellow P. 1994. The cDNA sequence and chromosomal location of the human SOX2 gene. Mamm Genome 5:640-642.

Tanaka S, Kamachi Y, Tanouchi A, Hamada H, Jing N, Kondoh H. 2004 Interplay of SOX and POU factors in regulation of the Nestin gene in neural primordial cells. Mol Cell Biol 24:8834-8846.

Thomson JA, Itskovitz-Eldor J, Shapiro SS, Waknitz MA, Swiergiel JJ, Marshall VS, Jones JM. 1998. Embryonic stem cell lines derived from human blastocysts. Science 282:1145-1147.

van Praag H, Schinder AF, Christie BR, Toni N, Palmer TD, Gage FH 2002. Functional neurogenesis in the adult hippocampus. Nature 415 : $1030-1034$

Wagner JP, Black IB, DiCicco-Bloom E. 1999. Stimulation of neonatal and adult brain neurogenesis by subcutaneous injection of basic fibroblast growth factor. J Neurosci 19:6006-6016.

Wood HB, Episkopou V. 1999. Comparative expression of the mouse Sox1, Sox2 and Sox3 genes from pre-gastrulation to early somite stages. Mech Dev 86:197-201.

Zappone MV, Galli R, Catena R, Meani N, De Biasi S, Mattei E, Tiveron C, Vescovi AL, Lovell-Badge R, Ottolenghi S, Nicolis SK. 2000. Sox2 regulatory sequences direct expression of a (beta)-geo transgene to telencephalic neural stem cells and precursors of the mouse embryo, revealing regionalization of gene expression in CNS stem cells. Development 127:2367-2382.

Zhang C, Basta T, Jensen ED, Klymkowsky MW. 2003. The beta-catenin/ VegT-regulated early zygotic gene Xnr5 is a direct target of SOX3 regulation. Development 130:5609-5624.

Zhang C, Basta T, Hernandez-Lagunas L, Simpson P, Stemple DL, Artinger KB, Klymkowsky MW. 2004. Repression of nodal expression by maternal B1-type SOXs regulates germ layer formation in Xenopus and zebrafish. Dev Biol 273:23-37.

Zhang SC, Wernig M, Duncan ID, Brustle O, Thomson JA. 2001. In vitro differentiation of transplantable neural precursors from human embryonic stem cells. Nat Biotechnol 19:1129-1133.

Zhang YA, Okada A, Lew CH, McConnell SK. 2002. Regulated nuclear trafficking of the homeodomain protein otx1 in cortical neurons. Mol Cell Neurosci 19:430-446.

Zigova T, Pencea V, Wiegand SJ, Luskin MB. 1998. Intraventricular administration of BDNF increases the number of newly generated neurons in the adult olfactory bulb. Mol Cell Neurosci 11:234-245. 